\title{
Note on the late effect of vagotomy and pyloroplasty on the maximal acid response to histamine
}

\author{
ALVIN M. GELB AND HENRY D. JANOWITZ \\ From the Division of Gastroenterology, the Department of Medicine, \\ Mount Sinai Hospital, New York, N.Y., U.S.A.
}

EDITORIAL SYNOPSIS There is scanty information on the longer terms of vagotomy on the maximal acid response to histamine and this paper records a follow-up study on eight patients. Seven of the eight patients maintained a sustained reduction in both free and total acid secretion one to three years after vagotomy and of the same order of magnitude as found in the immediate post-operative period. One woman who had a $40 \%$ reduction immediately post-operatively, had a return in acid secretory capacity two years later to levels slightly above those found pre-operatively.

Several years ago in this journal we (Gelb, Baronofsky, and Janowitz, 1961) reported on the immediate effect of vagotomy and pyloroplasty on the gastric secretion of acid in man as measured by the augmented histamine test. In 16 patients who were thought to have had a complete vagotomy there was an average reduction of $69 \%$ in free acid secretion and an average reduction of $61 \%$ in total acid secretion. When six patients were retested three months later, the same order of reduction was still present (free acid, $80 \%$, total acid $77 \%$ ). Three patients with an incomplete vagotomy, as measured by a positive insulin response post-operatively, had no significant change in acid secretion. The augmented histamine test was particularly well suited for this study because of its repeatability.

Since our report, the ability of nerves, particularly autonomic nerves, to repair themselves after damage has been stressed. In addition to regeneration, an incompletely severed nerve may repair itself by sprouting side branches, which assume the function of the whole nerve. The ability of nerves to heal in these ways is, of course, relevant to the problem of vagotomy. Sprouting of a few remaining fibres of an incompletely divided vagus may explain, in some instances, failure of vagotomy to prevent ulcer recurrence. Sprouting may also explain the conversion of a negative insulin response to a positive one with the passage of time. The duration of time required for sprouting depends upon the percentage of intact fibres. If only $1 \%$ of fibres remain, recovery may require even up to one year (Murray, 1962).

Because of these considerations, and because there is scant information on the longer effects of vagotomy on the maximal acid response to histamine, we thought it of interest to study again, after vago-

TABLE I

LATE CHANGES IN AUGMENTED HISTAMINE TEST IN PATIENTS WITH VAGOTOMY AND PYLOROPL.ASTY

\begin{tabular}{|c|c|c|c|c|c|c|c|c|c|c|}
\hline \multirow{3}{*}{$\begin{array}{l}\text { Case } \\
\text { No. } \\
\\
1\end{array}$} & \multirow{3}{*}{$\begin{array}{c}\text { Pre-operative } \\
12.6\end{array}$} & \multicolumn{4}{|c|}{ Free Acid (mEq.10.5 hr.) } & & \multicolumn{4}{|c|}{ Total Acid (mEq./O.5 hr.) } \\
\hline & & \multicolumn{2}{|c|}{$\begin{array}{l}\text { Immediate } \\
\text { Post-operative }\end{array}$} & \multicolumn{2}{|c|}{ Late Change } & re-Operative & \multicolumn{2}{|c|}{$\begin{array}{l}\text { Immediate } \\
\text { Post-operative }\end{array}$} & \multicolumn{2}{|c|}{ Late Change } \\
\hline & & $2 \cdot 3$ & $-10 \cdot 3(-82 \%)$ & $\begin{array}{ll}\text { (1) } & 1.8 \\
\text { (2) } & 1.0\end{array}$ & $\begin{array}{l}-10.8(-86 \%) \\
-11.6(-92 \%)\end{array}$ & $19 \cdot 1$ & $6 \cdot 1$ & $-15 \cdot 0(-79 \%)$ & $\begin{array}{l}3 \cdot 8 \\
2 \cdot 0\end{array}$ & $\begin{array}{l}-15 \cdot 3(-80 \%) \\
-17 \cdot 1(-90 \%)\end{array}$ \\
\hline 4 & $7 \cdot 6$ & $7 \cdot 0$ & $-0.6(-8 \%)$ & (1) $3 \cdot 8$ & $-3.8(-50 \%)$ & $13 \cdot 0$ & $9 \cdot 6$ & $-3.4(-26 \%)$ & 5.0 & $-8.0(-62 \%)$ \\
\hline 6 & 4.9 & 0.1 & $-4.8(-98 \%)$ & (1) 1.5 & $-3.4(-69 \%)$ & $8 \cdot 4$ & $0 \cdot 2$ & $-8 \cdot 2(-97 \%)$ & 3.4 & $-5.0(-60 \%)$ \\
\hline 8 & $19 \cdot 1$ & 5.9 & $-13 \cdot 2(-69 \%)$ & (1) 1.4 & $-17.7(-93 \%)$ & $26 \cdot 0$ & 7.9 & $-18 \cdot 1(-69 \%)$ & $6 \cdot 2$ & $-19 \cdot 8(-76 \%)$ \\
\hline 11 & $15 \cdot 3$ & $0 \cdot 1$ & $-15 \cdot 2(-99 \%)$ & (3) 4.5 & $-10.8(-71 \%)$ & $21 \cdot 3$ & 0.8 & $-20.5(-96 \%)$ & $6 \cdot 0$ & $-15 \cdot 3(-72 \%)$ \\
\hline 15 & $6 \cdot 4$ & $0 \cdot 1$ & $-6 \cdot 3(-98 \%)$ & $\begin{array}{l}\text { (1) } 0.0 \\
\text { (2) } 0.1\end{array}$ & $\begin{array}{l}-6.4(-100 \%) \\
-6.3(-98 \%)\end{array}$ & $10 \cdot 8$ & 0.4 & $-10.4(-96 \%)$ & $\begin{array}{l}0.0 \\
0.1\end{array}$ & $\begin{array}{l}-10.8(-100 \%) \\
-10.7(-99 \%)\end{array}$ \\
\hline $\begin{array}{l}18 \\
\text { Average }\end{array}$ & $5 \cdot 4$ & $0 \cdot 0$ & $\begin{array}{l}-5.4(-100 \%) \\
-8.0(-79 \%)\end{array}$ & (3) $2 \cdot 1$ & $\begin{array}{l}-3 \cdot 3(-61 \%) \\
-8 \cdot 2(-80 \%)\end{array}$ & $7 \cdot 1$ & $1 \cdot 5$ & $\begin{array}{l}-5.6(-79 \%) \\
-11.6(-77 \%)\end{array}$ & $2 \cdot 6$ & $\begin{array}{l}-4.5(-63 \%) \\
-11.8(-78 \%)\end{array}$ \\
\hline & $9 \cdot 7$ & $5 \cdot 8$ & $-3.9(-40 \%)$ & (2) $11 \cdot 7$ & $+2.0(+21 \%)$ & $12 \cdot 3$ & $7 \cdot 2$ & $-5.1(-41 \%)$ & $12 \cdot 6$ & $+0.3(+2 \%)$ \\
\hline
\end{tabular}

(1) One year after operation

(2) Two years after operation

(3) Three years after operation 
tomy and pyloroplasty, those patients who had had a significant reduction in acid secretion. Although we were successful in following up only eight patients, the results are of some interest, and perhaps will prompt others to re-study their patients after a longer time lapse.

The method of performing the augmented histamine test and calculating the results were as originally reported. Of the original group, eight were restudied: three after one year, three after two years, and two were restudied after three years. The results (Table I) reveal that seven of the eight patients maintained a sustained reduction in both free and total acid secretion one to three years after vagotomy, and of the same order of magnitude as found in the immediate post-operative period. One woman who had a $40 \%$ reduction immediately post-operatively, had a return in acid secretory capacity after two years to levels slightly above those found pre-operatively. Although it is possible that one of her tests was in error, this patient may represent an example of sprouting of nerves. Unfortunately, an insulin test was not performed post-operatively.

Clinically it is interesting that the seven patients who maintained their reduction in ability to secrete acid in response to histamine have done well and are free of pain. The one patient who is now responding as she did pre-operatively has had abdominal pains within the past year similar to those experienced pre-operatively.

\section{REFERENCES}

Gelb, A. M., Baronofsky, I. D., and Janowitz, H. D. (1961). The effect of vagotomy and pyloroplasty on the maximal acid responses to histamine. Gut, 2, 240-245.

Murray, J. G. (1962). Sprouting of nerves; some consequences of vagotomy and sympathectomy. Gastroenterology, 42, 197-200. 